\section{PELICANS NESTING AT LAST MOUNTAIN LAKE}

\author{
DEAN NERNBERG, 75 Woodward \\ Avenue, Regina, Saskatchewan. \\ S4R $3 \mathrm{H} 3$
}

White Pelicans successfully bred in 1984 at the north end of Last Mountain Lake after 12 unsuccessful years. Their success may have been due to the drought, which unfortunately hampered the breeding success of many other avian species. The drought caused a significant lowering of the water level in Last Mountain Lake and thus many rocky and sandy islands were exposed that would not have been in a normal year. This increased the suitable nesting habitat for the pelicans and other colonial island nesters.

On 9 July Greg Hergott and I, as employees of the Canadian Wildlife Service, censused the colonial birds that nest on Perry's Point, on the east side of the lake. On the point there were no birds, however the island off the point was covered by a large number. When we approached the island Ring-billed Gulls flew up and an estimate of 1300 individuals was made, including young, of which most were able to fly. Our disturbance as we waded toward the island scared away the adult Double-crested Cormorants and pelicans. We knew the cormorants were nesting because of the large chimney-stack nests, but assumed the pelicans were only roosting. An estimate of 60 adult cormorants was made, though we were not sure if some were off feeding. The number of cormorant chicks were estimated from a distance to lessen the disturbance; there were approximately 320 chicks. Some of the cormorant nests still had eggs. A group of nests at the edge of the colony had no young, but 30 eggs in total.

At the end of the cormorant colony we were surprised when we saw some nests with larger eggs. They were pelican nests. The counting was done quickly so the adults would return and avoid overexposure of eggs to the sun. There were 26 eggs, some of which were in nests and some just lying in the sand. There were a few nests with one or three eggs but the majority had two. On 14 August Lyle Ludwig of the Canadian Wildlife Service revisted the island to make a count of 218 cormorant nests and 9 young pelicans.

Earlier in the summer Lyle found a small colony of pelicans on an island northwest of Perry's Point. There were three nests with five eggs in total. On 24 July Lyle, Michael Krystal and I visited the island to check the colony and found only one egg with no adults in sight. The reason for the disappearance of the eggs could not be found.

Why the pelicans have not bred for the past 12 years is unknown, however it is most likely due to the

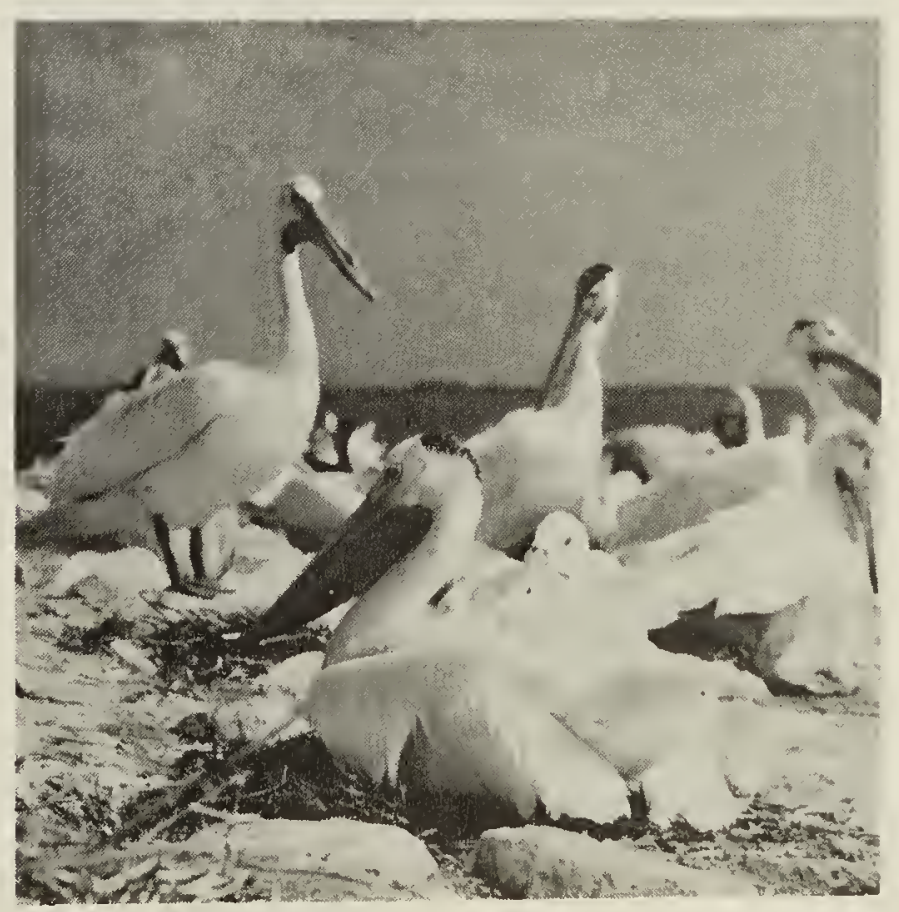

Pelican and cormorant colony Unknown 
large amount of disturbance by boaters and fishermen. I hope that it does not take another drought before the pelicans of Last Mountain Lake again breed successfully.

I would like to thank Clint Jorgenson for help with this article and Ed Driver and Phil Taylor for their encouragement to write it.

\section{EXOTIC BIRD IN SASKATOON}

CHRISTOPHER J. ESCOTT, 271

Sylvian Way, Saskatoon, Saskatchewan. S7H 5G1

On 18 July 1984, as I was engaged in strenuous soccer match, I sighted a most unusual bird. The game was being played on Fairview Field, which is bordered on east and north sides by the City of Saskatoon tree nursery. I saw the bird, and a glimpse was all I had, at about $2030 \mathrm{~h}$. The sun had set a short time earlier, but the sky was clear and the early dusk visibility was good, although colours were a bit hard to distinguish.

A single bird burst out of the Manitoba Maples on the east side of the field. It was the size and shape of a Mourning Dove, but perhaps more slender with smaller head and shorter neck. The tail was longish and tapered, with a suggestion of white corners. The most striking features were the large white wing patches near mid-wing from wrist to greater coverts, and the black area between these white patches and the wing tips.

The bird flew in a dipping, swooping semi-circle out over the sidelines of the field and back into the poplars at the northeast corner. At the crest of each swoop the tail fluttered and the bird uttered a clear whistled "klee klee klee..." at a rate of about 1 call/second. The calling continued briefly after the bird had re-entered the trees. It was not seen or heard again.

My initial reaction was "Wow! A Whited-winged Dove!" I was even more excited when I recalled hearing of an unconfirmed sighting of a White-winged Dove near Rice Lake in the summer of 1983. But I was nagged with doubts: a White-winged Dove should be chunkier than a Mourning Dove, have a less tapered tail, and sing like a hoarse domestic rooster. I checked Bent's Life Histories of North American Gallinaceous Birds, and Cottam and Trefethen's Whitewings, but couldn't resolve these doubts.

Then, several weeks later as I was walking in downtown Saskatoon, I heard a plaintive whistling noise coming through the open window of a car. I glanced in the back seat and saw a caged bird, a pet which is rather expensive but available in most local pet stores. It met the description of my mystery bird! It is the same length as a Mourning Dove; it has a long tapering tail; it is generally greyish in colour (males have bright yellow faces, but females are greyish all over); it has white wing patches which are a diagnostic feature in flight; and its call is a prolonged "queel queel" according to Slater's A Field Guide to Australian Birds. What was my mystery bird? I believe it was a female of the species Nymphicus hollandicus, a Cockatiel! I'm glad I've solved this riddle. I wonder if anyone else has seen strange things which may have been escaped exotics! 